\title{
Validitas buku ilmiah populer penyu untuk siswa SMA kawasan pesisir

\section{Irwandi ${ }^{1,}{ }^{*}$, Atiek Winarti ${ }^{2}$, Muhammad Zaini ${ }^{3}$}

Pendidikan biologi, Pascasarjana, Universitas Lambung Mangkurat, Indonesia

${ }^{1}$ wandyirwandy28@gmail.com *, ${ }^{2}$ atiekwin_kimia@ulm.ac.id, ${ }^{3}$ balittra_32@yahoo.co.id

* Korespondensi penulis

\begin{tabular}{|c|c|}
\hline Informasi art & ikel \\
\hline Riwayat artike & \\
\hline Diterima & 28 Maret 2018 \\
\hline Revisi & 13 Juli 2018 \\
\hline Dipublikasikan & 17 Agustus 2018 \\
\hline Kata kunci: & \\
\hline Buku ilmiah & ouler \\
\hline Penyu & \\
\hline Validitas & \\
\hline
\end{tabular}

\section{Keyword:}

Popular science books

Turtle

Validity

\begin{abstract}
ABSTRAK
Pendidikan lingkungan perlu ditunjang dengan sumber belajar yang relevan. Sumber belajar menggunakan buku ilmiah populer dipadukan dengan potensi lingkungan siswa menjadi solusi dalam mengatasi permasalahanpermasalahan pada proses pembelajaran. Siswa akan lebih mudah mengikuti karena dekat dengan kehidupan siswa, sehingga menciptakan pembelajaran yang menyenangkan, menantang, dan menerapkan proses pembelajaran bervariasi. Penelitian pengembangan bertujuan untuk menguji validitas prototipe buku ilmiah populer yang berjudul "Penyu Penyangga Kehidupan Pulau Sembilan Kotabaru". Metode pengembangan yang digunakan ialah Plomp dan Nieveen yang dibatasi pada fase evaluasi formatif. Uji data dilakukan pada siswa kelas XI SMAN 1 Pulau Sembilan dengan jumlah tiga orang siswa. Pengambilan data menggunakan instrumen lembar validasi dan angket keterbacaan siswa. Data validitas dianalisis secara deskriptif kuantitatif. Hasil analisis dari aspek validitas memperoleh nilai rata-rata 89,42\% masuk dalam kategori sangat valid. Adapun uji keterbacaan memperoleh nilai rata-rata $87,82 \%$ dengan kategori sangat baik. Berdasarkan hasil di atas, buku ilmiah populer yang dikembangkan menarik, efektif dan efisien untuk digunakan dalam pembelajaran.
\end{abstract}

\section{ABSTRACT}

Validity of the popular turtle scientific book for coastal high school students'. Environmental education needs to be supported by relevant learning resources. Learning resources using popular scientific books combined with the potential of the student's environment become a solution to overcome the problems in the learning process. Students will be easier to follow because it is close to students' lives, thus creating learning that is fun, challenging, and applying a varied learning process. Development research aims to examine the validity of a popular scientific book prototype entitled "Penyu Penyangga Kehidupan Pulau Sembilan". The development methods used are Plomp and Nieveen which are limited to the formative evaluation phase. Data testing was carried out on students of class XI of SMAN 1 Pulau Sembilan with a total of three students. Data retrieval using the instrument validation sheet and student readability questionnaire. Validity data were analyzed descriptively 
quantitative. The results of the analysis of the validity aspect obtained an average value of $89.42 \%$ in the very valid category. The readability test obtained an average value of $87.82 \%$ with a very good category. Based on the results above, popular scientific books developed are interesting, effective and efficient for use in learning.

\section{Pendahuluan}

Peraturan Pemerintah Nomor 32 tahun 2013 tentang Perubahan Atas Peraturan Pemerintah Nomor 19 tahun 2005 tentang Standar Nasional Pendidikan Pasal 17 mengamanatkan setiap satuan pendidikan untuk mengembangkan kurikulum sesuai dengan satuan pendidikan, potensi daerah, sosial budaya masyarakat setempat, dan siswa. Pembelajaran berbasis potensi lokal adalah pembelajaran yang memanfaatkan keunggulan atau potensi lokal suatu daerah sebagai salah satu sumber belajar. IPA dengan obyek pembelajaran alam, sangat bermakna apabila dikaitkan dengan lingkungan kehidupan siswa secara kontekstual. Artinya potensi lokal yang ada di daerah siswa akan menjadi pembelajaran bermakna baginya. Sumber belajar dengan mengintegrasikan potensi lokal mampu mempersiapkan siswa menjawab tantangan global dimasa mendatang, karena bekal semua dimensi belajar diberikan dalam pembelajaran IPA terintegrasi potensi/keunggulan lokal.

Salah satu bagian dari pendidikan yang penting yaitu proses pembelajaran. Menurut Daryanto (2010) proses pembelajaran merupakan sebuah proses komunikasi. Pesan dalam komunikasi dapat tersampaikan dengan baik kepada penerima (siswa), jika memiliki pengantar atau perantara (berupa sumber belajar) yang berkualitas baik. Sumber belajar yang memuat potensi lokal dari lingkungan sekitar siswa dan dikemas dengan tampilan yang menarik sesuai dengan perkembangan media informasi saat ini akan menjadikan pembelajaran IPA lebih efektif dan efisien.

Buku ilmiah populer (BIP) merupakan buku yang ditulis dengan cara yang mudah dimengerti dan dipahami oleh khalayak umum (Universitas Jendral Soedirman [UNSOED], 2016). Penulisan ilmiah populer menggunakan bahasa sederhana, ringkas, padat, teks harus sesuai tingkat pendidikan, ide-ide yang disampaikan harus saling berurutan, kalimat harus mengarahkan kepada pemahaman, dan kalimat yang digunakan harus jelas dan meyakinkan (Rakedzon \& Baram-Tsabari, 2017; Trim, 2014). BIP sebagai sumber belajar dapat digunakan untuk menarik minat dan perhatian siswa karena bentuk yang sederhana, memuat informasi-informasi, mudah untuk diingat dan dipahami, serta memberikan variasi tampilan agar tidak membosankan.

Penelitian mengenai buku ilmiah populer telah dilakukan oleh Nisa'ina, Prihatin, \& Fikri (2015) tentang pengaruh ekstrak daun kemangi (Ocium americanum L.) terhadap kualitas spermatozoa mencit (Mus musculus L.) dan pemanfaatannya sebagai buku ilmiah populer dinyatakan layak untuk digunakan sebagai buku bacaan masyarakat awam untuk menambah pengetahuan. Penelitian Innaja, Subchan, \& Suratno (2015) tentang uji resistensi ulat grayak (Spodoptera litura L.) terhadap insektisida bahan aktif sipermetrin pada tanaman tomat (Solanum lycopersicum L.) serta pemanfaatannya sebagai buku ilmiah populer juga dinyatakan layak digunakan sebagai buku bacaan. Zakyah, Suratno, \& Subchan (2016) yang melakukan pengembangan BIP tentang struktur pasir terhadap tingkat keberhasilan penetasan telur penyu hijau di Taman Nasional Meru Betiri, yang menyatakan bahwa buku ilmiah populer tersebut valid digunakan sebagai bahan bacaan.

BIP dapat dijadikan sumber belajar pendamping dalam pembelajaran di kelas sehingga dapat membantu siswa dalam memahami materi. Salah satu materi biologi yang dapat disampaikan melalui media BIP yaitu keanekaragaman hayati. Materi keanekaragaman hayati merupakan salah satu materi biologi yang diajarkan di kelas $X$ SMA. Salah satu sub materi yang terdapat dalam keanekaragaman hayati ialah 
keanekaragaman jenis. Keanekaragaman jenis akan dikaji yaitu keanekaragaman jenis penyu.

Pulau Sembilan merupakan salah satu kecamatan yang berada di Kabupaten Kotabaru, Kalimantan Selatan. Berdasarkan data Badan Pusat Statistik Kabupaten Kotabaru terdapat 5 Desa/Kelurahan yang tersebar di tiga pulau, yaitu Pulau Marabatuan, Pulau Matasiri, dan Pulau Maradapan. Kecamatan Pulau Sembilan memiliki sumber daya alam berupa hewanhewan laut yang sangat melimpah, wilayahnya sebagian besar masih alami dari pencemaran sehingga kuantitas dan kualitas sumber daya alam masih terjaga. Salah satu hewan laut yang masih banyak ditemukan di wilayah ini adalah penyu. Penyu merupakan hewan reptil yang hidup di laut dan merupakan hewan langka di dunia, sehingga perlu dijaga antara lain dengan memasukkan informasi terkait penyu dalam materi pembelajaran keanekaragaman jenis.

Berdasarkan hasil wawancara dengan guru biologi di SMAN 1 Pulau Sembilan, materi keanekaragaman hayati ini disampaikan dengan ceramah dan minim sumber belajar. Sumber belajar yang biasa dipakai yaitu buku teks pelajaran. Selain itu berdasarkan pengamatan pada buku ajar khususnya materi keanekaragaman hayati menunjukkan bahwa di dalam buku ajar hanya membahas secara umum tanpa penjelasan lanjut (Widayati, Rochmah, \& Zubaedi, 2009). Selain itu, belum adanya sumber belajar berbasis potensi lokal sehingga menyebabkan siswa kurang mengenal keanekaragaman hayati yang terdapat di wilayahnya sendiri. Padahal pengetahuan tersebut perlu untuk diketahui oleh siswa, agar siswa bisa lebih peduli dan menjaga keanekaragaman hayati yang terdapat di daerahnya. Adanya buku ilmiah populer sebagai sumber belajar diharapkan dapat membantu siswa memahami materi keanekaragaman hayati khususnya keanekaragaman jenis penyu melalui sumber belajar yang menarik dan berisi informasi penting dan jelas.

Berdasarkan uraian di atas, maka perlu dilakukan pengembangan buku ilmiah populer pada materi keanekaragaman hayati untuk menunjang kegiatan pembelajaran biologi pada siswa SMA yang berada di kawasan pesisir. Penelitian ini bertujuan untuk menghasilkan buku ilmiah populer yang valid.

\section{Metode}

Jenis penelitian pengembangan yang digunakan mengacu pada model penelitian pengembangan Plomp \& Nieveen meliputi penelitian pendahuluan (preliminary research), evaluasi formatif (prototyping phase), dan diseminasi (assesment phase). Namun penelitian ini hanya terfokus pada penelitian pendahuluan dan evaluasi formatif untuk menghasilkan buku ilmiah populer yang valid.

Studi pendahuluan dilakukan untuk menganalisis materi-materi esensial yang dapat digunakan dalam pembelajaran biologi. Penyusunan dan pengembangan draf buku bertujuan untuk merumuskan tujuan buku, menentukan komponenkomponen draf buku berdasarkan studi pendahuluan. Tahap yang dilakukan: 1) mengumpulkan informasi untuk mengkaji standar kompetensi dalam pembelajaran SMAN 1 Pulau Sembilan, 2) Melakukan pengkajian masalah-masalah yang terdapat pada pembelajaran materi keanekaragaman hayati terutama dalam sub materi keanekaragaman jenis, 3) Menemukan solusi dari permasalahan berdasarkan potensi wilayah Kecamatan Pulau Sembilan yaitu banyaknya penyu yang ditemukan, tetapi siswa ataupun masyarakat belum mengenal jenisnya serta manfaat dan pelestariannya seperti pada Tabel 1 .

Tabel 1. Analisis Kebutuhan buku ilmiah populer

\begin{tabular}{|c|c|c|}
\hline Masalah & Harapan & Solusi \\
\hline $\begin{array}{l}\text { Belum adanya pendataan jenis-jenis } \\
\text { penyu di Kecamatan Pulau Sembilan, } \\
\text { serta siswa maupun masyarakat } \\
\text { kurang mengetahui jenis, manfaat } \\
\text { serta pelestariannya }\end{array}$ & $\begin{array}{l}\text { Adanya sebuah sumber } \\
\text { belajar mengenai penyu } \\
\text { agar pelajar ataupun } \\
\text { masyarakat dapat } \\
\text { mengetahui jenis, manfaat, } \\
\text { dan cara pelestariannya }\end{array}$ & $\begin{array}{l}\text { Membuat sebuah buku yang } \\
\text { merupakan hasil dari } \\
\text { pendataan mengenai jenis, } \\
\text { manfaat, dan pelestarian } \\
\text { penyu yang ada di Kecamatan } \\
\text { Pulau Sembilan }\end{array}$ \\
\hline $\begin{array}{l}\text { Sumber belajar yang ada di sekolah } \\
\text { masih kurang dan masih sulit } \\
\text { dipahami, belum ada yang berbasis } \\
\text { potensi lokal, dan sumber belajar yang } \\
\text { ada belum membuat siswa untuk } \\
\text { berpikir }\end{array}$ & $\begin{array}{l}\text { Adanya sumber belajar } \\
\text { yang berbasis potensi lokal } \\
\text { dan mampu membuat siswa } \\
\text { lebih berpikir }\end{array}$ & $\begin{array}{l}\text { Mengembangkan buku ilmiah } \\
\text { populer berbasis potensi } \\
\text { lokal yang dibuat lebih } \\
\text { menarik dengan bahasa yang } \\
\text { sederhana sehingga mudah } \\
\text { dipahami oleh siswa. }\end{array}$ \\
\hline
\end{tabular}


Hasil dari penelitian pendahuluan menjadi dasar dalam penyusunan buku ilmiah populer berjudul "Penyu Penyangga Kehidupan Pulau Sembilan Kotabaru". Setelah itu, buku ilmiah populer divalidasi oleh ahli/pakar. Instrumen penelitian yang digunakan meliputi lembar validasi buku ilmiah populer yang diisi oleh 4 orang ahli/pakar pendidikan dan ahli biologi. Adapun uji keterbacaan dilakukan 3 siswa kelas XI SMAN 1 Pulau Sembilan dengan kemampuan akademik tinggi, sedang dan rendah. Hasil perhitungan yang telah diperoleh selanjutnya diubah menjadi data kuantitatif untuk kemudian dikualitatifkan sebagaimana Tabel 2.

Tabel 2. Kriteria validitas buku ilmiah populer

\begin{tabular}{ccl}
\hline Persentase & $\begin{array}{c}\text { Keterangan } \\
\text { validitas }\end{array}$ & Keterangan \\
\hline $80,1-100 \%$ & Sangat valid & $\begin{array}{c}\text { Tidak perlu } \\
\text { revisi }\end{array}$ \\
$60,1-80 \%$ & Valid & Revisi kecil \\
$40,1-60 \%$ & Cukup valid & Revisi kecil \\
$20,1-40 \%$ & Kurang valid & Revisi besar \\
$0-20 \%$ & Tidak valid & Revisi total \\
\hline
\end{tabular}

Data hasil uji perorangan (keterbacaan) diperoleh dari siswa melalui hasil angket. Persentase keterbacaan yang telah didapatkan dikategorikan dengan acuan Tabel 3.

Tabel 3. Kriteria uji keterbacaan buku ilmiah populer

\begin{tabular}{cc}
\hline Persentase & Kriteria \\
\hline $80,1 \%-100 \%$ & Sangat baik \\
$60,1 \%-80 \%$ & baik \\
$40,1 \%-60 \%$ & Sedang \\
$20,1 \%-40 \%$ & Tidak baik \\
$0,0 \%-20 \%$ & Sangat tidak baik \\
\hline
\end{tabular}

\section{Hasil dan pembahasan}

Validasi buku ilmiah populer (BIP) tentang "Penyu Penyangga Kehidupan Pulau Sembilan" draf I dilakukan oleh pakar sebanyak empat orang ahli/pakar sesuai dengan kriteria penulisan Rakedzon dan Baram-Tsabari (2017) dengan tujuan menghasilkan BIP yang dikembangkan valid. Hasil validasi dapat di lihat pada Tabel 4 .

Tabel 4. Hasil validasi ahli buku ilmiah populer

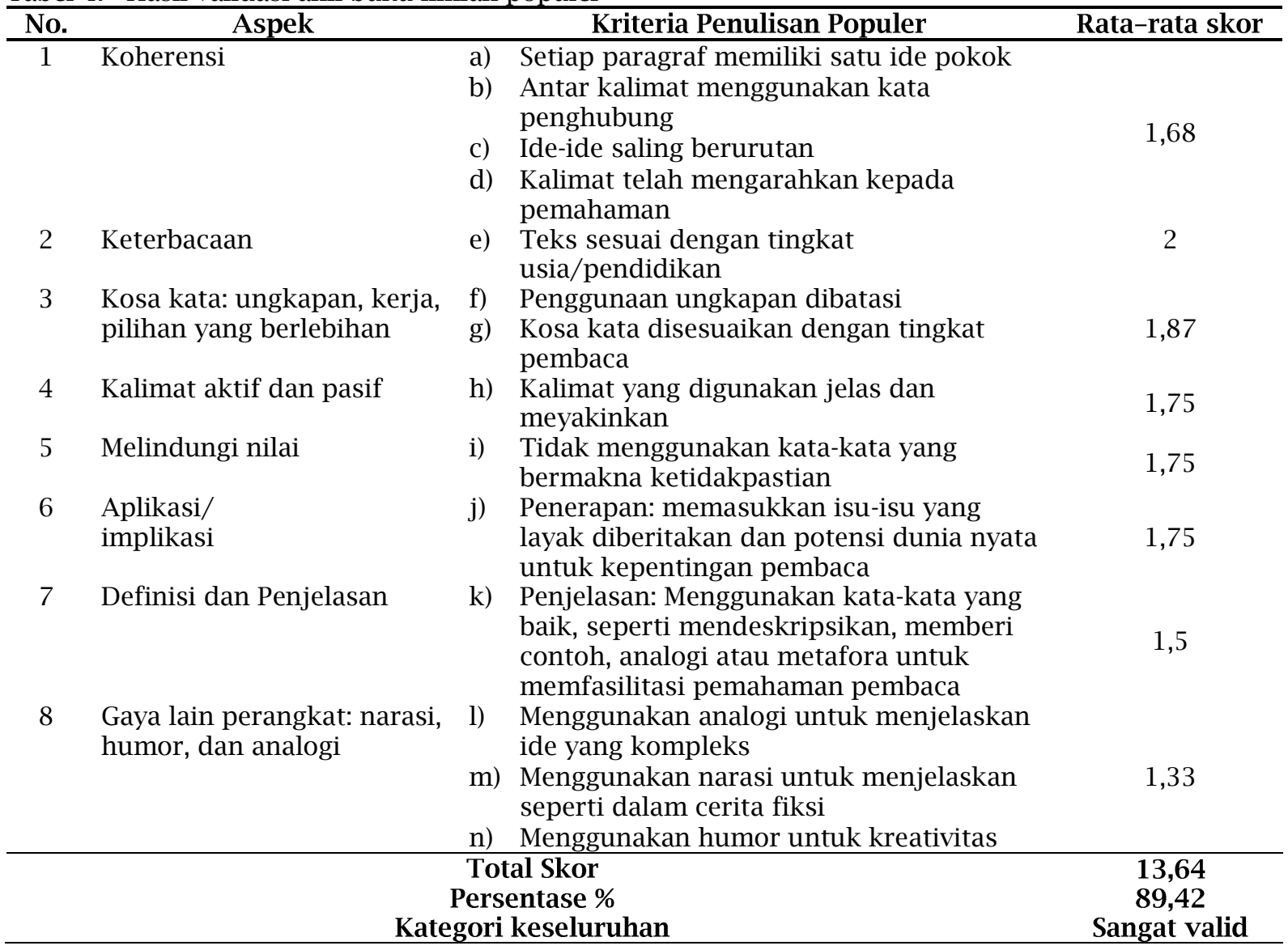

Validitas merupakan salah satu kriteria yang menentukan kualitas suatu produk
(Plomp \& Nieveen, 2007). Berdasarkan hasil validasi pada Tabel 4, BIP "Penyu Penyangga 
Kehidupan Pulau Sembilan Kotabaru" hasil pengembangan memperoleh nilai rata-rata 89,42\% masuk dalam kategori sangat valid. Adapun tampilan sampul buku ilmiah populer dapat di lihat pada gambar 1 .

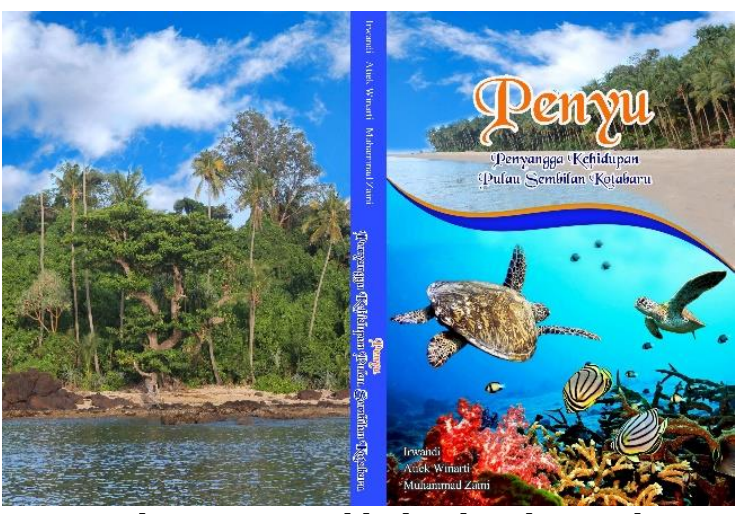

Gambar 1. Sampul buku ilmiah populer

Validasi pada BIP dibagi menjadi delapan aspek penilaian, meliputi aspek koherensi, aspek keterbacaan, aspek kosa kata (ungkapan, kerja, pilihan, yang berlebihan), aspek kalimat aktif dan pasif, aspek melindungi nilai (kata-kata yang bermakna ketidakpastian), aspek aplikasi, implikasi, aspek definisi dan penjelasan dan aspek gaya lain perangkat (narasi, humor, analogi).

Aspek pertama penilaian BIP yaitu koherensi, yang merupakan kaitan yang logis antara setiap bagian tulisan atau antara setiap kalimat dalam satu paragraf (Komaruddin, 2007). Kriteria yang dinilai dalam koherensi (1) setiap paragraf memiliki ide pokok, (2) antar kalimat menggunakan kata penghubung, (3) ide-ide saling berurutan, (4) kalimat telah mengarahkan kepada pemahaman (Rakedzon \& Baram-Tsabari, 2017). Berdasarkan hasil validasi dinyatakan sesuai dengan penulisan BIP. Kalimat yang digunakan pada BIP yang memenuhi kriteria koherensi akan meningkatkan hasil belajar siswa dan merangsang kemampuan berpikir siswa. Penggunaan kalimat pada BIP yang mengandung ide-ide yang runtut, saling berkaitan dan memberikan contoh yang sesuai dengan kehidupan sehari-hari siswa, sehingga dapat merangsang pemikiran siswa.

Aspek kedua yaitu kriteria keterbacaan yang menjadi fokus penilaian ialah kesesuaian antara kalimat pada BIP yang dikembangkan dengan tingkat usia atau tingkat pendidikan. Pada hasil validasi menunjukkan aspek keterbacaan BIP sangat sesuai. Karya ilmiah populer merupakan karangan yang ditulis dengan menggunakan bahasa yang populer sehingga mudah dimengerti oleh masyarakat dan menarik untuk dibaca (Dalman, 2012). Kalimat yang digunakan pada BIP mudah dipahami oleh siswa karena menggunakan kalimat yang efektif dan bahasa siswa sehari-hari yaitu bahasa Indonesia. Hal ini sejalan dengan Departemen Pendidikan Nasional (Depdiknas, 2004) yang menyatakan bahwa sumber belajar yang baik ditulis dengan bahasa yang baik. Jika siswa mudah memahami BIP maka akan mempengaruhi hasil belajar dan kemampuan berpikir kritis siswa. Penggunaan sumber belajar oleh siswa akan membantu dalam proses belajarnya (Wati, Susantini, \& Rahayu, 2015). Pembelajaran dengan menggunakan sumber belajar tersebut, siswa difasilitasi pada pencapaian tujuan pembelajaran. Sumber belajar berupa BIP membuat pembelajaran lebih kompleks karena akan memperkaya informasi siswa dalam mendapat pengetahuan.

Aspek ketiga penilaian BIP yaitu kriteria kosa kata yang menjadi fokus dalam penilaian adalah penggunaan ungkapan yang dibatasi, kosa kata yang digunakan sudah disesuaikan dengan tingkat pembaca. Penggunaan kosa kata pada BIP harus sesuai dengan tingkat pembaca agar lebih mudah dalam memahami maksud dan tujuan yang tertuang pada BIP. Hal ini sejalan dengan Arsyad (2016) menyatakan penggunaan kosa kata harus mencapai kejelasan, keteraturan, ketepatan makna, bahasa ilmiah bersifat lugas/padat. Kelugasan mengandung makna suatu maksud yang dapat diterima secara produktif oleh pihak lain. Dengan demikian, informasi yang disampaikan penulis akan diterima sama oleh setiap pembaca, hal ini dimaksudkan untuk menghindari adanya salah informasi. Penggunaan bahasa yang sederhana dapat dengan mudah diterima dan dipahami oleh siswa (Susilana \& Riyana, 2009).

BIP yang telah dikembangkan diharapkan dapat meningkatkan minat baca bagi siswa, agar berdampak positif pada hasil belajar sebab dengan minat seseorang akan melakukan sesuatu yang diinginkannya, seperti membaca buku karena sebagian besar kegiatan yang di lakukan dalam proses pembelajaran adalah membaca. Slameto (2010) mengatakan bahwa minat merupakan salah satu faktor yang mempengaruhi hasil belajar. Berdasarkan penelitian Wahab, Wasis dan Indana (2016) mengatakan selain minat 
baca, kemauan siswa untuk membaca juga dipengaruhi oleh ketersediaan sumber belajar yang menarik dan layak bagi siswa, sehingga mereka bisa membaca dalam kondisi yang senang dan santai. Membaca akan membuat seseorang memperoleh informasi secara lebih efektif. Sumber belajar membaca adalah salah satu solusi untuk mengatasi proses pembelajaran yang menjenuhkan dan membosankan, sumber belajar ini dipilih teks-teks bacaan yang menuntut siswa berpikir kritis guna memecahkan masalah (Yasin, Priyatni, \& Suyono, 2016). Pada BIP juga dibuatkan kolom khusus untuk melatih siswa dalam berpikir seperti Gambar 2.

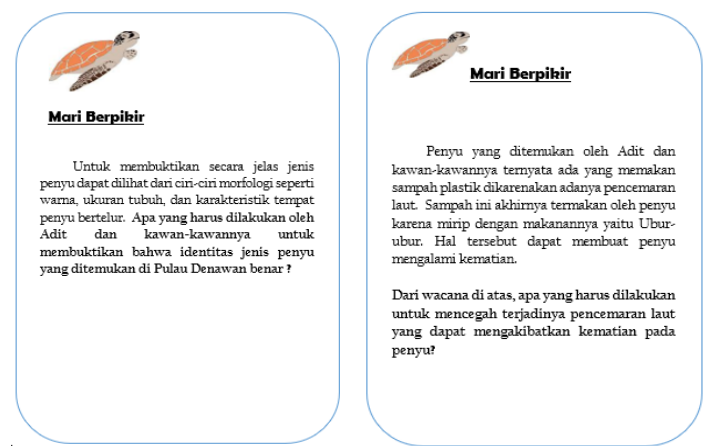

Gambar 2. Kolom khusus melatih kemampuan berpikir pada BIP

Siswa dengan memiliki kemampuan berpikir kritis dan minat baca yang tinggi, maka pada tahapan selanjutnya anak lebih berhati-hati dan kritis dalam menyikapi berbagai kejadian, fenomena atau persoalan pada era sekarang ini. Arus informasi saat ini sangat sulit dibendung sehingga anak bisa membaca serta menyaksikan kejadiankejadian positif maupun negatif yang terjadi di seluruh belahan dunia secara cepat (Sariyem, 2016).

Aspek keempat penilaian BIP yaitu kalimat aktif dan pasif. Menurut Rakedzon dan Baram-Tsabari (2017) buku ilmiah populer ditulis dengan struktur kalimat aktif. BIP yang diharapkan memenuhi kriteria jelas dan meyakinkan pembaca. Hasil validasi pada aspek ini sudah dikatakan sesuai. Penggunaan BIP telah memenuhi kriteria jelas dan meyakinkan pembaca berdasarkan komentar dari validator bahwa kalimat pada BIP sangat informatif dan komunikatif. Muslich (2010) menyatakan bahwa pemakaian bahasa yang komunikatif merupakan salah satu indikator kelayakan bahasa, artinya mengutamakan komunikasi antara penulis dan pembaca. Penulis tidak menonjolkan diri dengan penyebutan tertentu, tetapi hanya menggunakan bentuk-bentuk kalimat pasif. Menurut Pangesti (2012) kalimat efektif adalah kalimatnya jelas, padat, dan lugas sehingga dapat mudah dipahami oleh siswa. Selain itu, kalimat efektif juga jauh dari ambiguitas yang dapat mengaburkan makna. Selanjutnya, kalimat-kalimat itu disusun menjadi paragraf yang memiliki keutuhan makna pada masing-masing bab dan subbab.

Aspek kelima penilaian BIP yaitu melindungi nilai yang menjadi fokus pada BIP yang dikembangkan adalah tidak menggunakan kata-kata yang bermakna ketidakpastian. Berdasarkan hasil validasi aspek ini dinyatakan sangat sesuai. Artinya BIP yang dikembangkan memenuhi kriteria bersifat jelas dan objektif, tidak menimbulkan makna ganda, sehingga memudahkan pembaca (siswa) dalam menerima pengetahuan dan meningkatkan hasil belajar dan kemampuan berpikir siswa. Hal ini didukung oleh tidak adanya siswa yang merasa tidak jelas dengan kalimat-kalimat yang ada dalam teks BIP yang dikembangkan. Menurut Asyhari dan Silvia (2016) kalimat yang dituangkan pada BIP harus menggunakan bahasa yang jelas, objektif dan logis agar mudah diterima oleh pembaca. Dengan demikian makna yang terkandung dalam kata-kata yang digunakan dinyatakan secara tersurat. Hal ini dimaksudkan agar tidak ada peluang bagi penafsiran yang bertentangan. Sejalan dengan pendapat Hasruddin, Pratiwi dan Harahap (2014) menyatakan struktur kalimat harus mampu menggambarkan isi pesan yang disampaikan tidak mengandung makna ganda dan informasi yang tidak relevan. Oleh karena itu, penulis memiliki tanggung jawab besar untuk memastikan kejelasan bahasa, ketepatan informasi, serta menghindari kesalahan dalam percetakan dan penulisan (Mohammad \& Kumari, 2007). Hal ini agar memudahkan siswa dalam memahami isi yang terdapat dalam buku. Bahan pengajaran yang lebih jelas maknanya dapat lebih mudah dimengerti oleh siswa dan memungkinkan menguasai tujuan pembelajaran dengan baik (Sudjana \& Rivai, 2010).

Aspek keenam yaitu aplikasi dan implikasi yang menjadi fokus yaitu memasukkan isu-isu yang layak diberitakan dan potensi aplikasi dunia nyata untuk kepentingan pembaca (Rakedzon \& BaramTsabari, 2017). BIP yang dikembangkan dinyatakan sudah sesuai, dikarenakan 
sesuai dengan kondisi lingkungan siswa agar siswa diberi gambaran nyata mengenai potensi dan permasalahan yang ada di lingkungannya. Dengan demikian siswa lebih mudah memahami, mengkritisi, dan memberi solusi terhadap permasalahan yang terjadi dalam kehidupan sehari-hari.

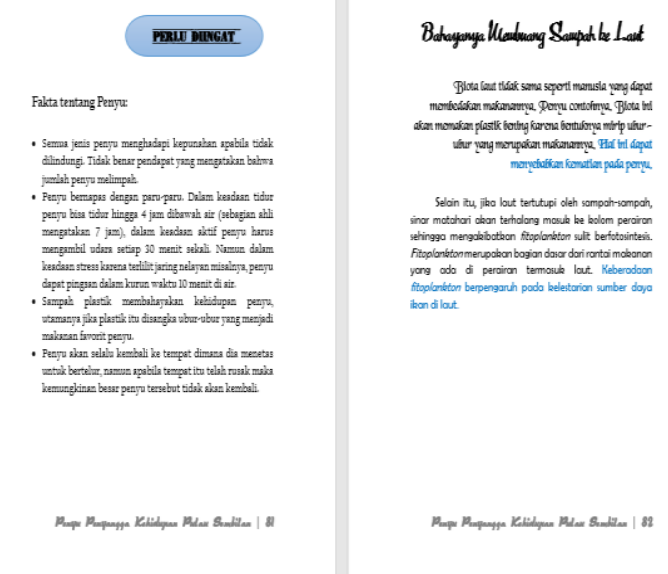

Gambar 3. Wacana mengenai masalah penyu dan kondisi lingkungan pesisir

BIP yang memuat potensi lokal, isu-isu lingkungan akan efektif digunakan dalam meningkatkan kognitif dan berpikir kritis siswa (Gambar 3). Sebagaimana yang dikatakan Wilujeng (2016) bahwa pembelajaran akan bermakna apabila IPA dengan obyek pembelajaran alam dikaitkan dengan lingkungan kehidupan siswa secara kontekstual. Dengan demikian, potensi lokal yang ada di daerah siswa akan menjadikan pembelajaran yang bermakna baginya. Sumber belajar dengan dipadukan potensi lokal akan menjadi bahan siswa menjawab tantangan global dimasa-masa mendatang, karena potensi/keunggulan lokal adalah bekal semua dimensi belajar yang diberikan dalam pembelajaran IPA. Sumber belajar kontekstual yang dikemas dengan lingkungan lokal akan lebih mudah untuk diikuti siswa. Hal ini akan menyediakan banyak informasi dan memperkaya pengalaman belajar siswa untuk mengeksplorasi potensi dan masalah yang ada di lingkungan sekitar siswa. Menurut Millah, Budipramana dan Isnawati (2012) pembelajaran IPA yang dikemas dengan tema kontekstual, yang dekat dengan kehidupan siswa dan materi yang diajarkan dikaitkan dengan situasi dunia nyata, akan dapat menciptakan kondisi pembelajaran yang menyenangkan, menantang, dan menerapkan proses pembelajaran bervariasi bagi siswa. Proses pembelajaran yang demikian, dapat menimbulkan dampak pada hasil belajar yang diperoleh siswa.

Aspek ketujuh yaitu penyampaian opini penulis harus mudah diterima oleh pembaca, hal ini berkaitan dengan aspek definisi dan penjelasan. BIP yang dikembangkan menggunakan kata-kata yang baik, dan memberikan contoh, analogi atau metafora untuk memudahkan pembaca. Berdasarkan hasil validasi aspek ini dinyatakan sudah sesuai. Ini menunjukkan definisi dan penjelasan dengan mendeskripsikan dan memberi contoh pada BIP dapat memudahkan siswa dalam memahami materi. Hal ini sependapat dengan Wibowo (2008) yang menyatakan bahwa penggunaan deskripsi pada buku harus jelas agar memudahkan pembaca dalam memahaminya, sehingga seolah-olah pembaca melihat langsung apa dijelaskan dalam BIP.

Aspek kedelapan yaitu aspek gaya lain perangkat antara lain narasi, humor dan analogi. Penulisan sumber belajar agar tidak memberikan kesan membosankan diperlukan kreativitas seperti analogi, humor dan narasi. Danaswari dan Roviati (2013) mengatakan agar sumber belajar (BIP) menarik untuk dibaca, maka diperlukan kreativitas contohnya menggunakan humor seperti pada Gambar 4. Jadi pada BIP perlu diselipkan humor untuk menambah variasi agar pengguna (siswa) tidak merasa jenuh dalam membaca. Menurut Ramdhayani, Ibrahim, dan Madlazim (2015) adanya analogi memudahkan siswa dalam memahami konsep suatu tulisan sehingga nantinya meningkatkan hasil belajar pengetahuan siswa. 


\section{Kamu Harus Tahu}

Begitu banyak manfaat Penyu bagi ekosistem laut tanpa kita sadari juga bermanfaat bagi kehidupan manusia. Lantas, apakah kita akan terus mengeksploitasi (memanfaatkan) penyu dengan memakan, memperdagangkan telur, membunuh, menangkap dan sebagainya hanya untuk kepuasan batin manusia?

\footnotetext{
Penyu merupakan satwa yang HARUS dilindungi bukan hanya oleh Pemerintah, Perjanjian Internasional, dan LSM, tetapi kita sebagai manusia yang merasakan akan pentingnya hewan ini juga WAJB ikut serta dalam menjaga dan melindunginya.
}

"Gemulai gerakanmu dalam air begitu mermpesona, ada yang memuja dan melestarikanmu, tetapi lebih banyak

\section{yang memburu, menyantap, dan merusak}

\author{
lingkungan hiduphu"
}

(Trisno Utomo)

Gambar 4. Contoh aspek perangkat gaya lain dari buku ilmiah populer

Setelah melalui tahap validasi, maka dilanjutkan dengan uji keterbacaan siswa. Uji keterbacaan dilakukan untuk menganalisis sejauh mana tingkat keterbacaan dan kesulitan dari BIP yang dikembangkan Uji keterbacaan siswa dilakukan oleh tiga siswa dengan melihat kesalahan yang tampak nyata pada BIP "Penyu Penyangga Kehidupan Pulau Sembilan Kotabaru". Uji keterbacaan ini terbagi menjadi dua aspek yaitu aspek tampilan dan aspek penyajian materi. Hasil uji keterbacaan dituangkan pada Tabel 5 .

Tabel 5. Hasil uji keterbacaan siswa

\begin{tabular}{ccccccc}
\hline \multirow{2}{*}{ Aspek Penilaian } & \multicolumn{4}{c}{ Nilai (\%) } & \multirow{2}{*}{ Rata-rata (\%) } & Kriteria \\
\cline { 2 - 4 } & $\mathbf{S}_{\mathbf{1}}$ & $\mathbf{S}_{\mathbf{2}}$ & $\mathbf{S}_{\mathbf{3}}$ & & \\
\hline Aspek Tampilan & 95 & 95 & 90 & & 93.33 & Sangat baik \\
Aspek Penyajian Materi & 90.62 & 84.37 & 78.12 & 84.37 & Sangat baik \\
\hline Rata-Rata & $\mathbf{9 2 . 3 0}$ & $\mathbf{8 8 . 4 6}$ & $\mathbf{8 2 . 6 9}$ & $\mathbf{8 7 . 8 2}$ & Sangat baik \\
\hline
\end{tabular}

Hasil uji keterbacaan siswa diketahui bahwa BIP berisi konsep yang menarik minat baca karena berhubungan dengan kondisi lingkungan sehari-hari siswa. Menurut Khairiyah, Tjandrakirana dan Widodo (2016) mengatakan bahwa keterbacaan (readibility) merupakan tolak ukur tentang kesesuaian atau tidaknya materi yang ada pada bahan bacaan yang dikembangkan bagi pembaca (siswa). Tingkat keterbacaan BIP, berkaitan erat dengan aspek atau teknik penyajian dan bahasa yang digunakan. Dalam penyusunan BIP memakai bahasa yang tepat, jelas, mudah dipahami, dan komunikatif. Pemilihan atau penggunaan bahasa yang demikian membantu mempercepat penyampaian dan penguasaan materi ajar oleh siswa.

BIP yang dikembangkan memuat gambar-gambar beserta keterangan sehingga memperjelas dan memudahkan pengguna. Sejalan dengan pernyataan Depdiknas (2004) bahwa gambar pada sumber belajar harus memiliki nomor atau nama sebagai identitas, sehingga akan memudahkan pengguna dalam memahaminya. Selain itu ilustrasi yang terdapat pada bahan ajar juga sesuai dengan materi yang dibahas. Hal tersebut menunjukkan bahwa BIP memenuhi salah satu ciri bahan ajar yang baik karena dilengkapi dengan gambar dan keteranganketerangannya (Gambar 5). Lebih lanjut Mulyati (2002) mengatakan gambar/foto pada sumber belajar berfungsi memperjelas informasi, membantu ingatan dan pemahaman, memberikan variasi agar tidak membosankan, dan memperindah agar menarik minat pembaca.

Badan Standar Nasional Pendidikan (BSNP, 2006) menyatakan bahwa dalam sumber belajar harus terdapat contohcontoh yang dekat dengan lingkungan sehari-hari, sehingga merangsang pemikiran siswa untuk mencoba dan mengaplikasikan pengetahuan yang diperoleh. BIP telah memberikan contoh 
yang sesuai dengan kondisi lingkungan siswa seperti tersedia pada Gambar 6. Hal ini agar siswa memiliki peluang untuk menjadi kreatif dan inovatif. Melalui penyajian seperti ini siswa akan mendapatkan pemahaman yang baik tentang materi yang terdapat dalam buku ajar, sehingga akan terbentuk transfer of learning dari segala sesuatu yang dipelajari dari buku ke dalam kehidupan nyata seharihari.
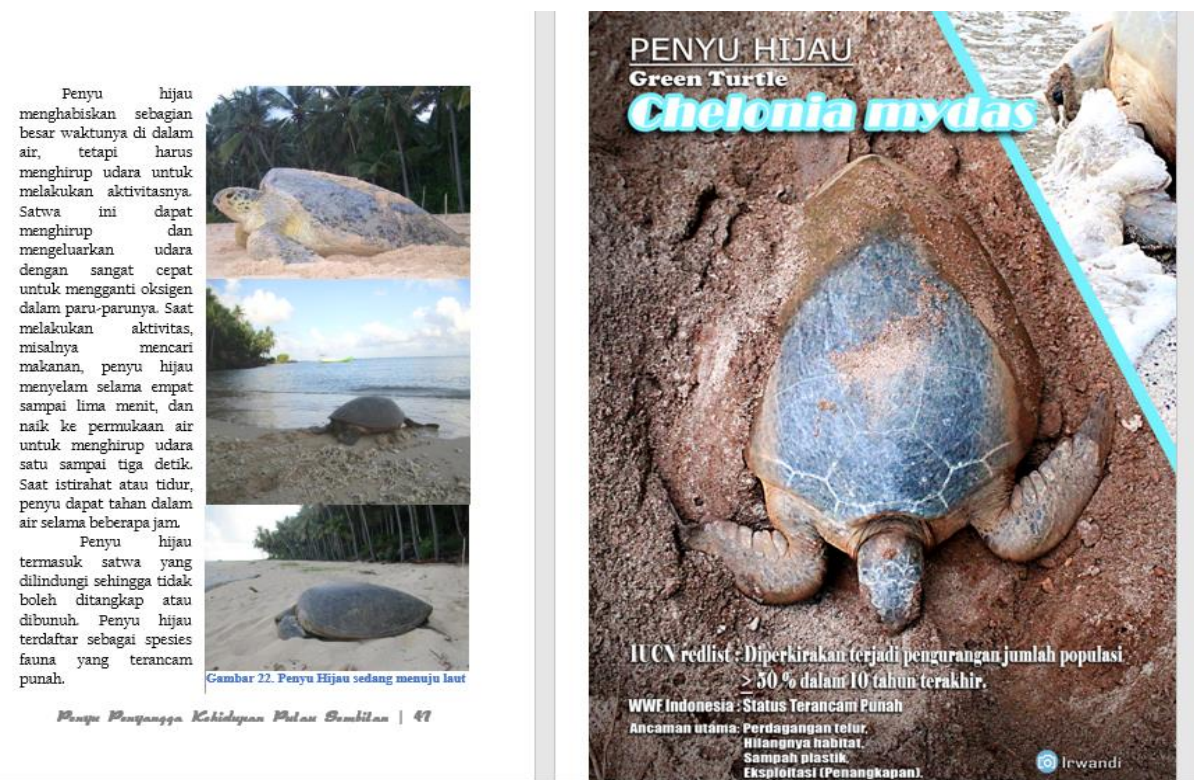

Gambar 5. Penambahan foto, ilustrasi dan variasi pada buku ilmiah populer

Secara menyeluruh BIP yang dikembangkan dapat dipahami siswa, sesuai dengan tingkat pendidikan siswa SMA dan menarik terutama bagi siswa, sehingga BIP yang dikembangkan dapat dilanjutkan pada uji coba tahap kecil untuk mengevaluasi penggunaan BIP tersebut.

Berdasarkan uraian di atas, maka secara keseluruhan BIP yang dikembangkan valid, artinya telah memenuhi kaidah dalam penulisan ilmiah populer yang menarik sesuai dengan sasaran penulisan BIP tersebut. BIP yang dikembangkan diharapkan dapat menambah minat baca siswa, sehingga dapat meningkatkan kognitif siswa yang masih rendah sesuai dengan hasil survei Trends International Mathematics and Science Study (TIMSS) dan Programme for International Student Assesment (PISA) mutu pendidikan di Indonesia masih rendah.
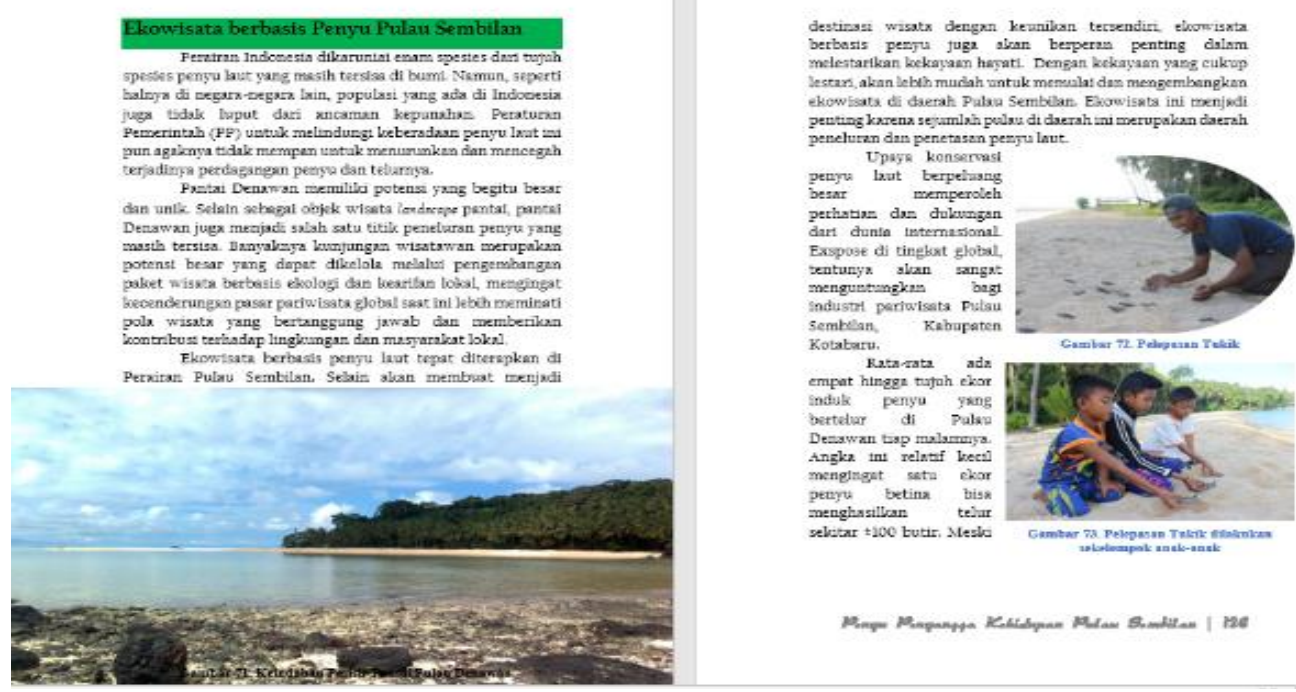

Gambar 6. Contoh isi BIP yang sesuai dengan kehidupan sehari-hari siswa 


\section{Simpulan}

Secara keseluruhan BIP berjudul "Penyu Penyangga Kehidupan Pulau Sembilan Kotabaru" yang dikembangkan dinyatakan sangat valid dengan persentase $89,42 \%$ berdasarkan hasil validasi ahli/pakar. Sedangkan pada uji keterbacaan BIP memperoleh skor rata-rata $87,82 \%$ berada pada kategori sangat baik. Hasil ini menunjukkan bahwa buku ilmiah populer (BIP) yang dikembangkan bersifat kontekstual, memiliki tampilan yang menarik, bahasa yang sederhana sehingga siswa lebih mudah memahami dan mempelajari materi yang ada pada buku ilmiah populer (BIP).

\section{Referensi}

Arsyad, A. (2016). Media pembelajaran (Revisi). Jakarta: Rajawali Pers.

Asyhari, A., \& Silvia, H. (2016). Pengembangan media pembelajaran berupa buletin dalam bentuk buku saku untuk pembelajaran IPA terpadu. Jurnal Ilmiah Pendidikan Fisika Al-Biruni, 5(1), 1-13. https://doi.org/10.24042/jpifalbiru ni.v5i1.100

Badan Standar Nasional Pendidikan. Standar isi untuk satuan pendidikan dasar dan menengah. , (2006).

Dalman. (2012). Menulis Karya Ilmiah. Diambil dari http://www. rajagrafindo.co.id/produk/menuliskarya-ilmiah/

Danaswari, R. W., \& Roviati, E. (2013). Pengembangan bahan ajar dalam bentuk media komik untuk meningkatkan hasil belajar siswa kelas x SMAN 9 Cirebon pada pokok bahasan ekosistem. Scientiae Educatia: Jurnal Pendidikan Sains, 2(2). https://doi.org/10.24235/sc. educatia.v2i2.477

Daryanto. (2010). Media pembelajaran. Yogyakarta: Gava Media.

Departemen Pendidikan Nasional. Pedoman umum pengembangan bahan ajar sekolah menengah atas. (2004).

Hasruddin, Pratiwi, N., \& Harahap, F. (2014). The development of problem-based applied microbiology textbook. International Journal of Education and Research, 2(9), 187-194. Diambil dari http://www.ijern.com/
journal/2014/September-

2014/16.pdf

Innaja, C. L., Subchan, W., \& Suratno, S. (2015). Uji resistensi ulat grayak (Spodoptera litura F.) terhadap insektisida bahan aktif sipermetrin pada tanaman tomat (Solanum lycopersicum L.) serta pemanfaatannya sebagai buku ilmiah populer (Universitas Jember). Diambil dari http://repository. unej.ac.id/bitstream/handle/12345

6789/67008/Choyrul Lulu\%27 Innaja - 110210103078.pdf? sequence $=1$

Khairiyah, U., Tjandrakirana, \& Widodo, W. (2016). Pengembangan perangkat pembelajaran IPA pendekatan scientific pada pokok bahasan pencemaran lingkungan untuk melatihkan life skills siswa SMP dan meningkatkan hasil belajar. Jurnal Penelitian Pendidikan Sain, 5(2), 1016-1022. Diambil dari https:// journal.unesa.ac.id/index.php/jpps /article/view/513/366

Komaruddin. (2007). Kamus istilah karya tulis ilmiah. Jakarta: Bumi Aksara.

Millah, E. S., Budipramana, L. S., \& Isnawati. (2012). Pengembangan buku ajar materi bioteknologi di kelas XII SMA IPIEMS Surabaya berorientasi sains, teknologi, lingkungan dan masyarakat (SETS). Berkala Ilmiah Pendidikan Biologi (BioEdu), 1(1), 1924. Diambil dari http:// jurnalmahasiswa.unesa.ac.id/index. php/bioedu/article/view/344/266

Mohammad, R. F., \& Kumari, R. (2007). Effective use of textbooks: A neglected aspect of education in Pakistan. Journal of Education for International Development, 3(1), 111. Diambil dari http://citeseerx.ist. psu.edu/viewdoc/download?doi=10 .1.1.533.1185\&rep=rep1\&type=pdf

Mulyati, Y. (2002). Pokok-pokok pikiran tentang penulisan modul bahan ajar dan diklat. Diambil dari http://file.upi.edu/Direktori/FPBS/J UR._PEND._BHS._DAN_SASTRA_IND ONESIA/196008091986012-YETI_ MULYATI/POKOK_PIKIRAN_TTG_M ODUL_(PPPG_02).pdf

Muslich, M. (2010). Text book writing: Dasar-dasar pemahaman, 
penulisan, dan pemakaian buku teks. Jogjakarta: Ar-Ruzz Media.

Nisa'ina, A., Prihatin, J., \& Fikri, K. (2015). Pengaruh ekstrak daun kemangi (Ocimum americanum L.) terhadap kualiatas spermatozoa mencit (Mus musculus L.) strain balb-c dan pemanfaatannya sebagai buku ilmiah populer (Universitas Jember). Diambil dari http://repository. unej.ac.id/bitstream/handle/12345 6789/65723/110210103069_Akmal ia Nisa'ina.pdf?sequence $=1$

Pangesti, F. (2012). Pengembangan bahan ajar pendidikan berpikir (kritis dan kreatif) berbahasa indonesia SMA melalui pembelajaran lintas mata pelajaran. Diambil dari http://jurnal-online.um.ac.id/data/ artikel/artikel285C26E2B1E88FF769 234C6254865E8A.pdf

Plomp, T., \& Nieveen, N. (2007). An introduction to educational design research. Proceedings of the Seminar Conducted at the East China Normal University, Shanghai (PR China), 2326. Shanghai: PR China.

Rakedzon, T., \& Baram-Tsabari, A. (2017). To make a long story short: A rubric for assessing graduate students' academic and popular science writing skills. Assessing Writing, 32, 28-42. https://doi.org/10.1016/ J.ASW.2016.12.004

Ramdhayani, E., Ibrahim, M., \& Madlazim, M. (2015). Pembelajaran sikap melalui analogi dalam mengajarkan biologi. JPPS (Jurnal Penelitian Pendidikan Sains), 5(1), 874-884. Diambil dari https://journal.unesa.ac.id/index.p hp/jpps/article/view/494

Sariyem, S. (2016). Kemampuan berpikir kritis dan minat baca dengan kemampuan membaca kritis siswa kelas tinggi SD Negeri di Kabupaten Bogor. Jurnal Pendidikan Dasar, 7(2), 329-340. https://doi.org/10.21009 /JPD.072.11

Slameto. (2010). Belajar \& faktor-faktor yang mempengaruhinya. Jakarta: PT Rineka Cipta.

Sudjana, N., \& Rivai, A. (2010). Media pengajaran. Bandung: Sinar Baru Algesindo.

Susilana, R., \& Riyana, C. (2009). Media pembelajaran:

Hakikat, pengembangan, pemanfaatan, dan penilaian. Google books

Trim, B. (2014). Pelatihan penulisan buku ilmiah populer. Bogor.

Universitas Jendral Soedirman. (2016). Panduan insentif penulisan buku, seminar, dan publikasi ilmiah. Diambil dari https://docplayer.info/ 29943300-Universitas-jenderalsoedirman-panduan-insentifpenulisan-buku-seminar-danpublikasi-ilmiah.html

Wahab, A., Wasis, W., \& Indana, S. (2016). Pengembangan bahan ajar komik pada materi sistem transportasi makhluk hidup untuk menumbuhkan minat baca dan meningkatkan hasil belajar. JPPS (Jurnal Penelitian Pendidikan Sains), 6(1), 1090-1096. Diambil dari https://journal.unesa.ac.id/index.p hp/jpps/article/view/524/377

Wati, H. M., Susantini, E., \& Rahayu, Y. S. (2015). Validitas bahan ajar berbasis metakognitif pada materi anabolisme karbohidrat. Berkala Ilmiah Pendidikan Biologi (BioEdu), 4(3), 957-962. Diambil dari http://jurnalmahasiswa.unesa.ac.id /index.php/bioedu/article/view/13 $423 / 12322$

Wibowo, W. (2008). Berani menulis artikel. Jakarta: Gramedia Pustaka Utama.

Widayati, S., Rochmah, \& Zubaedi. (2009). Biologi. Jakarta: Pusat Perbukuan Departeman Pendidikan Nasiona.

Wilujeng, I. (2016). Pengintegrasian potensi lokal dalam pembelajaran IPA alternatif peningkatan daya saing global. Prosiding Seminar Nasional IPA VII, 680-688. Yogyakarta: Universitas Negeri Yogyakarta.

Yasin, M., Priyatni, E. T., \& Suyono, S. (2016). Implementasi bahan ajar membaca berbasis masalah untuk melatih kemampuan berpikir kritis dan pemecahan masalah siswa kelas VIII SMPN 25 Malang. Cendekia: Jurnal Pendidikan Dan Pembelajaran, 10(2), 197-206. https://doi.org/ 10.30957/cendekia.v10i2.191

Zakyah, Suratno, \& Subchan, W. (2016). Pengaruh struktur pasir terhadap tingkat keberhasilan penetasan telur penyu hijau (Chelonia mydas L.) di Sukamade Taman Nasional meru betiri serta pemanfaatannya sebagai 
buku ilmiah populler (Universitas Jember). Diambil

dari

http://repository.unej.ac.id/bitstrea

m/handle/123456789/79032/Zaky ah - $120210103086 \quad$ \%23.pdf?

sequence $=1$ 